\title{
Integrated earned value analysis and their impact on project success
}

\author{
Fatemeh Nouban ${ }^{1 *}$, Nour Alij12 ${ }^{2}$, Mohammad Tawalbeh ${ }^{2}$ \\ 1*Assist. Prof. Dr., Near East University -Faculty of Civil and Environmental Engineering, Nicosia, Mersin 10, Turkey \\ ${ }^{2}$ Researcher, Near East University -Faculty of Civil and Environmental Engineering, Nicosia, Mersin 10, Turkey
}

fatemeh.nouban@neu.edu.tr, nourshan2002@outlook.com, tawalbeh993@ hotmail.com

\begin{abstract}
The project management system has many tools and techniques to control projects' main elements schedule, cost, quality, risk, communications and procurements to attain project success and high performance. Earned value analysis (EVA) is the most effective tool to measure project performance which is widely used by many organisations such as Defence Acquisition University; National Aeronautics and Space Administration; Society of Cost Estimates and Analysis; and Project Management Institute (PMI) to measure project performance and control it through cost and schedule, which are illustrated into graphs to forecast the project results to be shared and reported to top management, stakeholders and client in regular basis taking into consideration the other factors such as risk management, project environment, quality, safety, control charts, and sustainability to attain highly performance. Proposed methodology in the presented paper to implement the integrated EVA in an effective and uncomplicated way to attain project success and high performance using an automated sheet to perform analysis for an anonymous hospital design project with the total duration of seven months and illustrates and summarises the key factors based on previous studies and project examples.
\end{abstract}

KEYWORDS: Earned value, integrated, project management, budget, cost, risk management, project success

\section{INTRODUCTION}

Well defined performance management system (PMS) is a significant element used to align operational and strategic levels (McAdam, 2014) by providing extensive information for project performance through earned value management (EVM) analysis and reporting. Many studies have been illustrated the effectiveness of applying earned value analysis (EVA) such as De Marco (2009), Chou (2010) and Souza (2019) to meet project requirements, and some proposed a framework that includes design and operation in EVA system to provide a guideline for the effects of project environment characteristics that leads to project success (Joby, 2018), also EVA was proposed as design control mechanism by using triangular fuzzy time by applying bottom-up hierarchy estimate process and a triangular fuzzy number was used to control multi-product planning problems (Bagherpour, 2010). On the other hand, many studies reported EVA weaknesses such as there is no check system for the quality of work in addition to variations in cumulative earned value and physical work done on individual tasks (Lukas, 2008; Vargas, 2004).

\section{METHODOLOGY}

To implement integrated EVA in an effective and uncomplicated way to attain project success and high performance using an automated sheet to perform analysis for an anonymous hospital design project with total duration is seven months, the results are reported on a monthly-base cut-off, the proposed methodology is summarised in Fig. 1 and explained in the steps presented below.

EVM has three primary elements to conduct the analysis of the actual cost (AC), planned value (PV), and earned value $(\mathrm{EV})$, to monitor and measure project variances such as schedule variance (SV) and cost variance $(\mathrm{CV})$, in addition to the status indicators cost performance index (CPI), schedule performance index (SPI), estimate at completion (EAC), estimate to complete (ETC), and to complete performance index (TCPI) which summarised in Tables 1, 2 and 3.

Table 1. EVM elements

\begin{tabular}{ll}
\hline EVM shortcut & Definition (PMI, 2017) \\
\hline PV (BCWS) & Planned Value (Budgeted Cost of Work schedule). \\
EV (BCWP) & Earned Value (Budgeted Cost of Work Performed). \\
AC & Actual Cost Labor consists of \\
& $\bullet \quad$ Materials \\
& - Equipment \\
& $-\quad$ Fixed costs such as subcontractors. \\
\hline
\end{tabular}




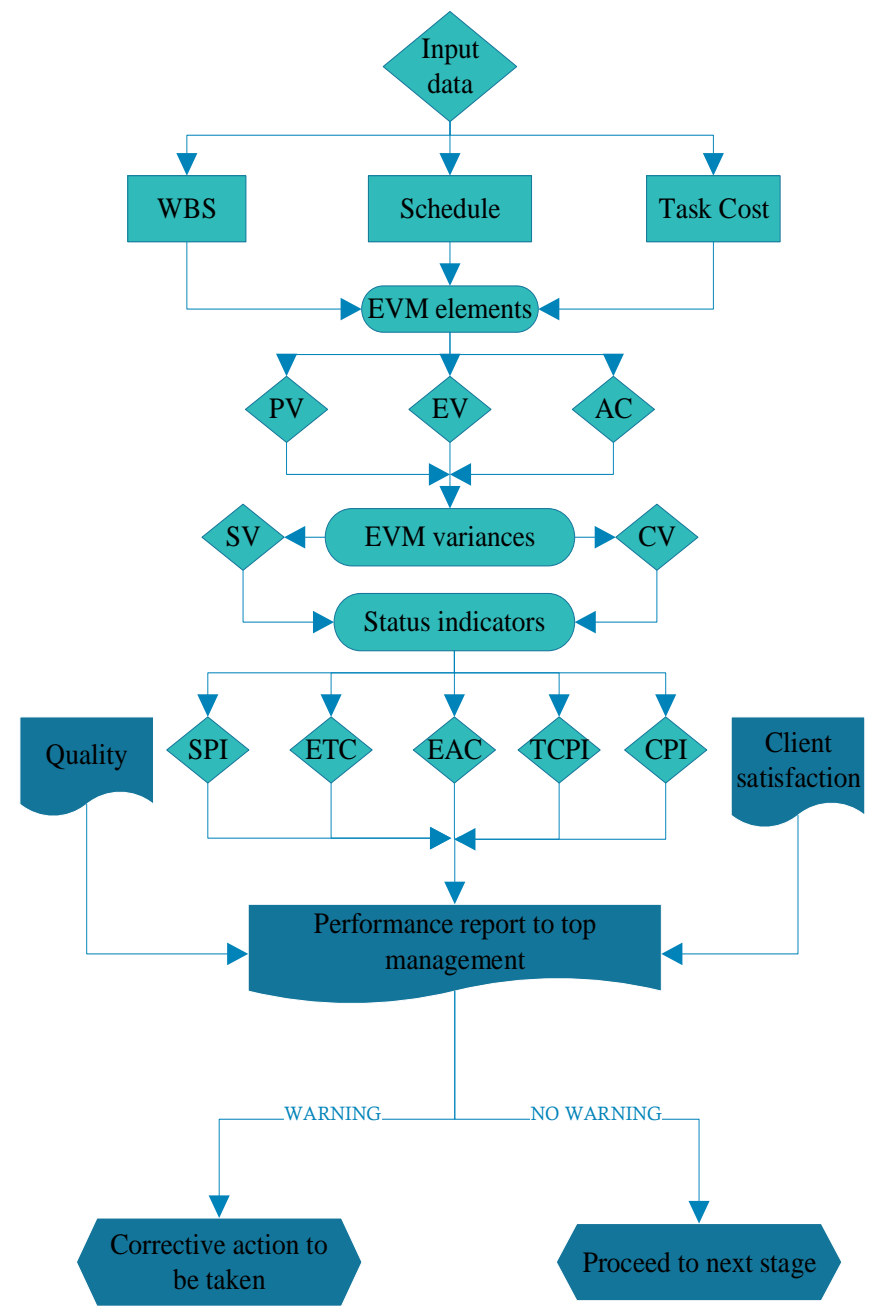

Fig. 1. The proposed methodology for integrated EVA

Table 2. EVM variances

\begin{tabular}{|c|c|c|c|}
\hline Shortcut & Definition & $\begin{array}{l}\text { Examples and } \\
\text { formula }\end{array}$ & Indications \\
\hline SV & $\begin{array}{l}\text { Schedule } \\
\text { variance }\end{array}$ & 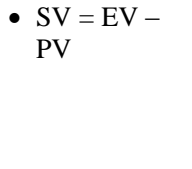 & $\begin{array}{l}\text { - On schedule }=0 \text { value } \\
\text { - } \text { Ahead schedule = } \\
\text { positive value } \\
\text { - Behind schedule = } \\
\text { negative value }\end{array}$ \\
\hline $\mathrm{CV}$ & $\begin{array}{l}\text { Cost } \\
\text { variance }\end{array}$ & - $\begin{array}{l}\mathrm{CV}=\mathrm{EV}- \\
\mathrm{AC}\end{array}$ & $\begin{array}{l}\text { - On budget = } 0 \text { value } \\
\text { - Under Budget }= \\
\text { positive value } \\
\text { - Over Budget = negative } \\
\text { value }\end{array}$ \\
\hline
\end{tabular}

Table 3. Status indicators

\begin{tabular}{|c|c|c|c|}
\hline Shortcut & Definition & Examples and formula & Indications \\
\hline SPI & $\begin{array}{l}\text { Schedule } \\
\text { performance } \\
\text { Index }\end{array}$ & - $\mathrm{SPI}=\mathrm{EV} / \mathrm{PV}$ & $\begin{array}{l}\text { - } \text { On schedule, SPI = } 1 \\
\text { - } \\
\begin{array}{l}1 \\
1\end{array} \\
\text { - } \\
\quad \text { Behind schedule, SPI } \\
<1\end{array}$ \\
\hline CPI & $\begin{array}{l}\text { Cost } \\
\text { performance } \\
\text { index }\end{array}$ & - $\mathrm{CPI}=\mathrm{EV} / \mathrm{AC}$ & $\begin{array}{l}\text { - } \text { On budget, CPI = } 1 \\
\text { - Under Budget, } \mathrm{CPI}>1 \\
\text { - } \text { Over Budget, } \mathrm{CPI}<1\end{array}$ \\
\hline EAC & $\begin{array}{l}\text { Estimate at } \\
\text { completion }\end{array}$ & $\begin{array}{l}-\mathrm{EAC}=\mathrm{AC}+\mathrm{BAC}- \\
\mathrm{EV} \\
-\mathrm{EAC}=\mathrm{BAC} / \mathrm{CPI} \\
-\mathrm{EAC}=\mathrm{AC}+\{(\mathrm{BAC} \\
-\mathrm{EV}) /(\mathrm{CPI} * \mathrm{SPI})\}\end{array}$ & $\begin{array}{l}\text { - Perform budget to date } \\
\text { - Based on CPI to } \\
\text { continue in future } \\
\text { - Based on the } \\
\text { efficiency rate of CPI } \\
\text { \& SPI }\end{array}$ \\
\hline ETC & $\begin{array}{l}\text { Estimate to } \\
\text { complete }\end{array}$ & $\mathrm{ETC}=\mathrm{EAC}-\mathrm{AC}$ & - \\
\hline TCPI & $\begin{array}{l}\text { To complete } \\
\text { performance } \\
\text { index }\end{array}$ & $\begin{array}{l}-\mathrm{TCPI}=(\mathrm{BAC}-\mathrm{EV}) /(\mathrm{BAC}- \\
\mathrm{AC}) \\
-\mathrm{TCPI}=(\mathrm{BAC}-\mathrm{EV}) /(\mathrm{EAC}- \\
\mathrm{AC})\end{array}$ & $\begin{array}{l}\text { - Complete on plan } \\
\text { - Complete to current } \\
\text { EAC }\end{array}$ \\
\hline
\end{tabular}

\subsection{Completion percentage}

The completion percentage of each task needs to be determined, monitored and reported on a cumulative Mo.ly basis for each task, taking into consideration rework, modifications and client acceptance. As shown in Table 4, the following indicators are considered:

- Not started $0 \%$

- In progress $10-95 \%$

- Completed and accepted by client $100 \%$

Table 4. Percentage of completion for each task reported on a monthly-base cut-off

\begin{tabular}{|c|c|c|c|c|c|c|c|c|c|c|}
\hline \multicolumn{3}{|c|}{$\%$ of Cum. } & $\begin{array}{l}\text { Mo. } \\
1\end{array}$ & $\begin{array}{l}\text { Mo. } \\
2\end{array}$ & $\begin{array}{l}\text { Mo. } \\
3\end{array}$ & $\begin{array}{l}\text { Mo. } \\
4\end{array}$ & $\begin{array}{l}\text { Mo. } \\
5\end{array}$ & $\begin{array}{l}\text { Mo. } \\
6\end{array}$ & $\begin{array}{l}\text { Mo. } \\
7\end{array}$ & \multirow[b]{2}{*}{ Cum. } \\
\hline WBS & $\begin{array}{l}\text { Task } \\
\text { Nam } \\
\text { e }\end{array}$ & $\begin{array}{l}\text { TBC } \\
(\boldsymbol{\epsilon})\end{array}$ & $\begin{array}{l}31 \\
\text { Aug. }\end{array}$ & $\begin{array}{l}\text { 30 } \\
\text { Sep. }\end{array}$ & $\begin{array}{l}31 \\
\text { Oct. }\end{array}$ & $\begin{array}{l}\text { 30 } \\
\text { Nov. }\end{array}$ & $\begin{array}{l}31 \\
\text { Dec. }\end{array}$ & $\begin{array}{l}31 \\
\text { Jan. }\end{array}$ & $\begin{array}{l}28 \\
\text { Feb. }\end{array}$ & \\
\hline 1 & B01 & 20,000 & $40 \%$ & $45 \%$ & $15 \%$ & & & & & $100 \%$ \\
\hline 2 & GF & 20,000 & $25 \%$ & $-45 \%$ & $30 \%$ & & & & & $100 \%$ \\
\hline 3 & F01 & 16,000 & & & $25 \%$ & $40 \%$ & $35 \%$ & & & $100 \%$ \\
\hline 4 & F02 & 18,000 & & & & $60 \%$ & $30 \%$ & $10 \%$ & & $100 \%$ \\
\hline 5 & F03 & 8,000 & & & & & & $70 \%$ & $30 \%$ & $100 \%$ \\
\hline 6 & F04 & 8,000 & & & & & & $70 \%$ & $30 \%$ & $100 \%$ \\
\hline & 705 & 5,000 & & & & & & $40 \%$ & $60 \%$ & $100 \%$ \\
\hline 8 & VO- 1 & 4,000 & & & & & & $10 \%$ & $90 \%$ & $100 \%$ \\
\hline 9 & VO-2 & 6,000 & & & & & & & $100 \%$ & $100 \%$ \\
\hline 10 & VO-3 & 5,000 & & & & & & & $100 \%$ & $100 \%$ \\
\hline
\end{tabular}

All approved variations such as variations order number 1, 2 and 3 in the illustrated example should be reported and included in EVA and avoid to add unapproved variations or changed work to EVA and resource utilisation. Malmanagement reserve and contingency cost should be excluded while calculating the total budget cost (TBC) for each task.

\subsection{Planned value (PV)}

Planned value as a monetary element to be determined at project commencement and as per the well-defined schedule and decomposed scope which be transformed into oriented work breakdown structure (WBS) (Ruskin, 2005), as shown 
in Table 5. A fundamental methodology was proposed by Long Chena (2016) to improve the performance prediction of PV by advanced modelling PV before project execution by providing reliable forecasted results about $\mathrm{EV}$ and $\mathrm{AC}$ performance.

Table 5. planed values were set up at the commencement of the project

\begin{tabular}{|c|c|c|c|c|c|c|c|c|c|}
\hline \multicolumn{10}{|c|}{ Planned Value (PV) or Budgeted Cost of Work Scheduled (BCWS) } \\
\hline \multirow[b]{2}{*}{ WBS } & \multirow[b]{2}{*}{ Task name } & \multirow[b]{2}{*}{ TBC $(€)$} & Mo. 1 & Mo. 2 & Mo. 3 & Mo. 4 & Mo. 5 & Mo. 6 & Mo. 7 \\
\hline & & & 31 Aug. & & & & $\begin{array}{l}31 \\
\text { Dec. }\end{array}$ & $\begin{array}{l}31 \\
\text { Jan. }\end{array}$ & $\begin{array}{l}28 \\
\text { Feb. }\end{array}$ \\
\hline 1 & B01 & 20,000 & $30 \%$ & $40 \%$ & $30 \%$ & & & & \\
\hline 2 & GF & 20,000 & $30 \%$ & $40 \%$ & $30 \%$ & & & & \\
\hline 3 & F01 & 16,000 & & & $20 \%$ & $40 \%$ & $40 \%$ & & \\
\hline 4 & F02 & 18,000 & & & & $50 \%$ & $50 \%$ & & \\
\hline 5 & F03 & 8,000 & & & & & & $80 \%$ & $20 \%$ \\
\hline 6 & F04 & 8,000 & & & & & & $80 \%$ & $20 \%$ \\
\hline 7 & F05 & 5,000 & & & & & & $50 \%$ & $50 \%$ \\
\hline 8 & vo-1 & 4,000 & & & & & & $10 \%$ & $90 \%$ \\
\hline 9 & vo-2 & 6,000 & & & & & & & $100 \%$ \\
\hline 10 & vo-3 & 5,000 & & & & & & & $100 \%$ \\
\hline $\begin{array}{l}\text { Total } \\
\text { (€) }\end{array}$ & I budget & 110,000 & 12,000 & 16,000 & 15,200 & 15,400 & 15,400 & 15,700 & 20,300 \\
\hline $\begin{array}{l}\text { Cumu } \\
\text { (PV) }\end{array}$ & $\begin{array}{l}\text { ulative } P \\
(€)\end{array}$ & Planned Value & 12,000 & 28,000 & 43,200 & 58,600 & 74,000 & 89,700 & 110,000 \\
\hline
\end{tabular}

\subsection{Earned value (EV)}

The earned value for completed task budget was determined based on the actual percentage of completion considering measurement criteria and organisation project management system, as shown in Table 6.

Table 6. Earned value based on $\%$ of complete

\begin{tabular}{|c|c|c|c|c|c|c|c|c|c|}
\hline \multirow{2}{*}{ WBS } & \multirow{2}{*}{$\begin{array}{l}\text { Task } \\
\text { name }\end{array}$} & \multirow{2}{*}{$\begin{array}{l}\text { TBC } \\
(€)\end{array}$} & \multirow{2}{*}{$\begin{array}{l}\text { Mo.1 } \\
\begin{array}{l}31 \\
\text { Ang. }\end{array}\end{array}$} & \multirow{2}{*}{$\begin{array}{l}\text { Mo. } 2 \\
30 \\
\text { Sep. }\end{array}$} & \multirow{2}{*}{$\begin{array}{l}\text { Mo. } 3 \\
\text { 31 } \\
\text { Oct. }\end{array}$} & \multirow{2}{*}{$\begin{array}{l}\text { Mo. } 4 \\
30 \text { Nov. }\end{array}$} & \multirow{2}{*}{$\begin{array}{l}\text { Mo. } 5 \\
31 \text { Dec. }\end{array}$} & \multirow{2}{*}{$\begin{array}{l}\text { Mo. } 6 \\
\text { J1 } \\
\text { Jan. }\end{array}$} & \multirow{2}{*}{$\begin{array}{l}\text { Mo. } 7 \\
28 \\
\text { Feb. }\end{array}$} \\
\hline & & & & & & & & & \\
\hline 1 & B01 & 20,000 & $40 \%$ & $45 \%$ & $15 \%$ & & & & \\
\hline 2 & GF & 20,000 & $25 \%$ & $45 \%$ & $30 \%$ & & & & \\
\hline 3 & F01 & 16,000 & & & $25 \%$ & $40 \%$ & $35 \%$ & & \\
\hline 4 & F02 & 18,000 & & & & $60 \%$ & $30 \%$ & $10 \%$ & \\
\hline 5 & F03 & 8,000 & & & & & & $70 \%$ & $30 \%$ \\
\hline 6 & F04 & 8,000 & & & & & & $70 \%$ & $30 \%$ \\
\hline 7 & F05 & 5,000 & & & & & & $40 \%$ & $60 \%$ \\
\hline 8 & vo-1 & 4,000 & & & & & & $10 \%$ & $90 \%$ \\
\hline 9 & vo-2 & 6,000 & & & & & & & $100 \%$ \\
\hline 10 & vo-3 & 5,000 & & & & & & & $100 \%$ \\
\hline \multicolumn{2}{|c|}{ Total EV (€) } & 110,000 & 13,000 & 18,000 & 13,000 & 17,200 & 11,000 & 15,400 & 22,400 \\
\hline \multicolumn{3}{|c|}{ Cumulative EV (€) } & 13,000 & 31,000 & 44,000 & 61,200 & 72,200 & 87,600 & 110,000 \\
\hline \multicolumn{10}{|c|}{ Weighted tasks $\%$ of Complete } \\
\hline WBS & $\begin{array}{l}\text { Task } \\
\text { name }\end{array}$ & TBC & $\begin{array}{l}31 \\
\text { Aug. }\end{array}$ & 30 Sep. & 31 Oct. & 30 Nov. & 31 Dec. & 31 Jan. & 28 Feb. \\
\hline 1 & B01 & $18.18 \%$ & $7.3 \%$ & $8.2 \%$ & $2.7 \%$ & $0.0 \%$ & $0.0 \%$ & $0.0 \%$ & $0.0 \%$ \\
\hline 2 & GF & $18.18 \%$ & $4.5 \%$ & $8.2 \%$ & $5.5 \%$ & $0.0 \%$ & $0.0 \%$ & $0.0 \%$ & $0.0 \%$ \\
\hline 3 & F01 & $14.55 \%$ & $0.0 \%$ & $0.0 \%$ & $3.6 \%$ & $5.8 \%$ & $5.1 \%$ & $0.0 \%$ & $0.0 \%$ \\
\hline 4 & F02 & $16.36 \%$ & $0.0 \%$ & $0.0 \%$ & $0.0 \%$ & $9.8 \%$ & $4.9 \%$ & $1.6 \%$ & $0.0 \%$ \\
\hline 5 & F03 & $7.27 \%$ & $0.0 \%$ & $0.0 \%$ & $0.0 \%$ & $0.0 \%$ & $0.0 \%$ & $5.1 \%$ & $2.2 \%$ \\
\hline 6 & F04 & $7.27 \%$ & $0.0 \%$ & $0.0 \%$ & $0.0 \%$ & $0.0 \%$ & $0.0 \%$ & $5.1 \%$ & $2.2 \%$ \\
\hline 7 & F05 & $4.55 \%$ & $0.0 \%$ & $0.0 \%$ & $0.0 \%$ & $0.0 \%$ & $0.0 \%$ & $1.8 \%$ & $2.7 \%$ \\
\hline 8 & vo-1 & $3.64 \%$ & $0.0 \%$ & $0.0 \%$ & $0.0 \%$ & $0.0 \%$ & $0.0 \%$ & $0.4 \%$ & $3.3 \%$ \\
\hline 9 & vo-2 & $5.45 \%$ & $0.0 \%$ & $0.0 \%$ & $0.0 \%$ & $0.0 \%$ & $0.0 \%$ & $0.0 \%$ & $5.5 \%$ \\
\hline 10 & vo-3 & $4.55 \%$ & $0.0 \%$ & $0.0 \%$ & $0.0 \%$ & $0.0 \%$ & $0.0 \%$ & $0.0 \%$ & $4.5 \%$ \\
\hline Total & & $100 \%$ & $11.82 \%$ & $16.36 \%$ & $11.82 \%$ & $15.64 \%$ & $10 \%$ & $14 \%$ & $20.36 \%$ \\
\hline Cumul & EV & & $11.82 \%$ & $28.18 \%$ & $40 \%$ & $55.64 \%$ & $65.64 \%$ & $79.64 \%$ & $100 \%$ \\
\hline
\end{tabular}

\subsection{Actual cost (AC)}

The actual cost budget to be reported regularly as per the organisation project management system and financial discipline as shown in Table 7.

Table 7. Actual costs were reported monthly

\begin{tabular}{lllllllll}
\hline & & Mo. 1 & Mo. 2 & Mo. 3 & Mo. 4 & Mo.5 & Mo. 6 & Mo. 7 \\
\cline { 2 - 8 } WBS & $\begin{array}{l}\text { Task } \\
\text { name }\end{array}$ & $\begin{array}{l}\mathbf{3 1} \\
\text { Aug. }\end{array}$ & $\begin{array}{l}\mathbf{3 0} \\
\text { Sep. }\end{array}$ & $\begin{array}{l}\mathbf{3 1} \\
\text { Oct. }\end{array}$ & $\begin{array}{l}\mathbf{3 0} \\
\text { Nov. }\end{array}$ & $\begin{array}{l}\mathbf{3 1} \\
\text { Dec. }\end{array}$ & $\begin{array}{l}\mathbf{3 1} \\
\text { Jan. }\end{array}$ & $\begin{array}{l}\mathbf{2 8} \\
\text { Feb. }\end{array}$ \\
\hline $\begin{array}{l}\text { All } \\
(\boldsymbol{\epsilon})\end{array}$ & 12,000 & 16,000 & 17,000 & 16,500 & 16,000 & 16,000 & 18,000 \\
\hline $\begin{array}{l}\text { Cumulative } \\
\text { actual } \\
(\text { AC) }(\boldsymbol{\epsilon})\end{array}$ & cost & $\mathbf{1 2 , 0 0 0}$ & $\mathbf{2 8 , 0 0 0}$ & $\mathbf{4 5 , 0 0 0}$ & $\mathbf{6 1 , 5 0 0}$ & $\mathbf{7 7 , 5 0 0}$ & $\mathbf{9 3 , 5 0 0}$ & $\mathbf{1 1 , 5 0 0}$ \\
\hline
\end{tabular}

\subsection{Results and discussion}

Gathered information and calculations to be tabulated and represented in Fig. 2 to be shared and discussed with top management, clients and stakeholders as shown in Table 8 and Fig. 2, red values represent a warning signal for a project manager that project is not aligned with project baseline which can be presented with another form as exante control chart to alerts which proposed by Mortaji (2018).

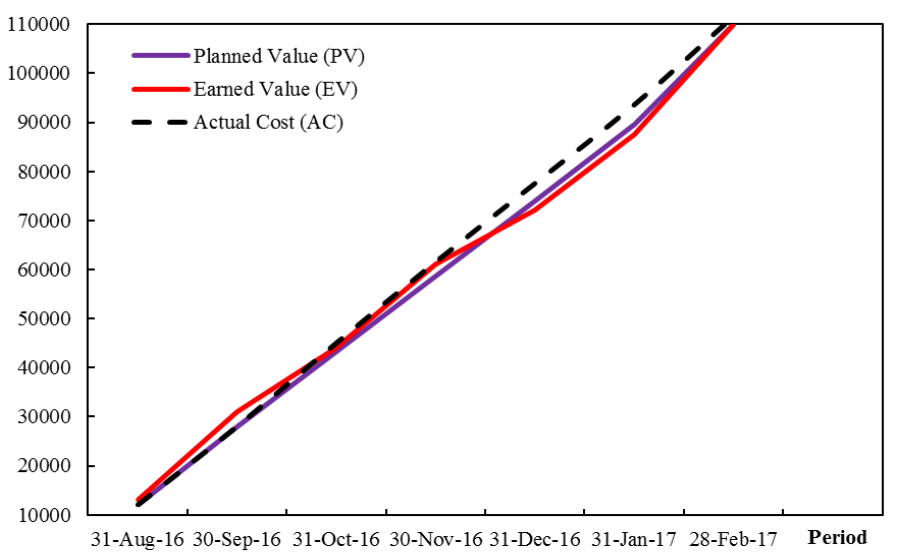

Fig. 2. EVM analysis chart

In the first and second months, project performance metrics show that the project cost variance $(\mathrm{CV})$ are positive values and CPI is higher than 1 , which indicate that project is under budget which is explained in Fig. 2 for the first and second months it shows that red line which represents $\mathrm{EV}$ is above hidden black line which represents $\mathrm{AC}$ and first means the project is under budget based on the project performance to second Mo. date it costs $99,534.84 €$ at completion with overall progress is $28.18 \%$ and certified accepted work from client is $7.27 \%$ and positive values for schedule variance and SPI is higher than 1, which indicates that the project is ahead schedule, which illustrated in Fig. 2 for reported months EV line is above PV line. 
Table 8. Overall project variances and status indicators

\begin{tabular}{|c|c|c|c|c|c|c|c|}
\hline & Mo. 1 & Mo. 2 & Mo. 3 & Mo. 4 & Mo. 5 & Mo. 6 & Mo. 7 \\
\hline & 12,000 & 28,000 & 43,200 & 58,600 & 74,000 & 89,700 & 110,000 \\
\hline \multicolumn{8}{|c|}{ Actual cost and earned value } \\
\hline $\begin{array}{l}\text { Cumulative } \\
\text { actual cost } \\
\text { (AC)-Hours } \\
\text { (€) }\end{array}$ & 12,000 & 28,000 & 45,000 & 61,500 & 77,500 & 93,500 & 111,500 \\
\hline $\begin{array}{l}\text { Cumulative } \\
\text { earned value } \\
\text { (EV)-Hours } \\
\text { (€) }\end{array}$ & 13,000 & 31,000 & 44,000 & 61,200 & 72,200 & 87,600 & 110,000 \\
\hline \multicolumn{8}{|c|}{ Project performance metrics } \\
\hline $\begin{array}{l}\text { Cost } \\
\text { variance } \\
\text { (CV }=\mathbf{E V} \text { - } \\
\text { AC) (€) }\end{array}$ & 1,000 & 3,000 & $-1,000$ & -300 & $-5,300$ & $-5,900$ & $-1,500$ \\
\hline $\begin{array}{l}\text { Schedule } \\
\text { variance } \\
\text { (SV }=\mathbf{E V} \text { - } \\
\text { PV) }(\boldsymbol{\epsilon})\end{array}$ & 1,000 & 3,000 & 800 & 2,600 & $-1,800$ & $-2,100$ & - \\
\hline $\begin{array}{l}\text { Cost } \\
\text { performance } \\
\text { index } \\
(\text { CPI = } \\
\text { EV/AC) }\end{array}$ & 1.083 & 207 & 0.978 & 0.995 & 0.932 & 0.937 & 0.987 \\
\hline Status & $\begin{array}{l}\text { Under } \\
\text { budget }\end{array}$ & $\begin{array}{l}\text { Under } \\
\text { budget }\end{array}$ & $\begin{array}{l}\begin{array}{l}\text { Over } \\
\text { budget }\end{array} \\
\end{array}$ & $\begin{array}{l}\begin{array}{l}\text { Over } \\
\text { budget }\end{array} \\
\end{array}$ & $\begin{array}{l}\begin{array}{l}\text { Over } \\
\text { budget }\end{array} \\
\end{array}$ & $\begin{array}{l}\begin{array}{l}\text { Over } \\
\text { budget }\end{array} \\
\end{array}$ & $\begin{array}{l}\text { Over } \\
\text { Budget }\end{array}$ \\
\hline $\begin{array}{l}\text { Schedule } \\
\text { performance } \\
\text { index (SPI = } \\
\text { EV/PV) }\end{array}$ & 1.083 & 207 & 1.019 & 1.044 & 0.976 & 0.977 & 10 \\
\hline Status & Ahead & Ahead & Ahead & Ahead & Behind & Behind & On \\
\hline $\begin{array}{l}\text { Estimated } \\
\text { cost at } \\
\text { completion } \\
\text { (EAC) (E) }\end{array}$ & $101,538.46$ & 99,354.84 & 112,500 & $110,539.22$ & $118,074.79$ & $117,408.68$ & 111,500 \\
\hline $\begin{array}{l}\text { Estimated } \\
\text { cost at } \\
\text { completion } \\
(\text { ETC) }(€)\end{array}$ & $89,538.46$ & $71,354.84$ & 67,500 & $49,039.22$ & $40,574.79$ & $23,908.68$ & - \\
\hline $\begin{array}{l}\text { Cumulative } \\
\% \quad \text { of } \\
\text { complete }\end{array}$ & $11.82 \%$ & $28.18 \%$ & $40 \%$ & $55.64 \%$ & $65.64 \%$ & $79.64 \%$ & $100 . \%$ \\
\hline $\begin{array}{l}\text { Cumulative } \\
\% \\
\text { certified of } \\
\text { work }\end{array}$ & $0 \%$ & $7.27 \%$ & $7.27 \%$ & $32.73 \%$ & $38.91 \%$ & $60.55 \%$ & $73.09 \%$ \\
\hline $\begin{array}{l}\text { Quality } \\
\text { status }\end{array}$ & High & high & low & low & accepted & accepted & accepted \\
\hline $\begin{array}{l}\text { Client } \\
\text { satisfaction } \\
\text { (yes, no) }\end{array}$ & Yes & Yes & No & No & No & No & Yes \\
\hline
\end{tabular}

In the third and fourth months, the project performance metrics show that the cost variance $(\mathrm{CV})$ is negative value and CPI is lower than 1 , which indicates that the project is over budget, which is explained in Fig. 2 for the third and fourth months, it shows that EV line is below AC line. It means the project is over budget, which requires from project manager to raise the flag that something in project is not aligned with project baseline which is explained by rework and unapproved changes have happened or the quality is not accepted. Based on the project performance for the fourthmonth date it costs $110,539.22 €$ at completion with overall progress is $55.64 \%$ and certified accepted work from client is $32.73 \%$ and positive values for schedule variance and SPI higher than 1 , which indicate project is ahead schedule, which illustrated in Fig. 2 for reported months EV line is above PV line.

In the fifth and sixth months, project performance metrics show that cost variance (CV) is negative values and CPI is lower than 1, which indicate that project is over budget, which is explained in Fig. 2 for the third and fourth months. It shows that EV line is below the AC line, which means that the project is over budget and negative values for schedule variance and SPI is lower than 1 , which indicates that the project is behind schedule, which is illustrated in Fig. 2 for reported months EV line is under PV line, which requires a corrective action to be discussed with top management and client to illuminate the situation and to realign the project progress with the project baseline. Based on the project performance to the sixth-month date it costs $117,408.68 €$ at completion which is higher than $110,000 €$ budget cost with overall progress is $79.64 \%$ and the certified accepted work from a client is $60.55 \%$.

In the seventh month, the project performance metrics show that CV is negative and CPI is lower than 1 , which indicates that the project is over budget which is explained in Fig. 2 for the end date. It shows that EV line is below the AC line which means the project is Over Budget and zero values for schedule variance and SPI equal 1 which indicate project is on schedule, which illustrated in Fig. 2 for reported months EV line is matched with PV line, which means the project finishes within the time with additional cost of $1500 €$.

Two metrics were added for quality status and client satisfaction which is sent to the client using appraisal form.

\section{Conclusions}

Integration of earned value management and the illustrated key factors is summarized in Fig. 3 based on the previous studies and project examples implemented effectively to control the project and its deliverance successfully.

Key factors are listed below:

- Risk management integration with EVM which has been explained by KhodaBandeh (2016) to achieve high performance and the proposed technique by Muriana (2017) to assess and prevent risk by estimating the risk for work progress status (WPS) and address their impact which results in a positive impact to mitigate risk.

- Including sustainability instead of scope in the business case to monitor the product life cycle. Based on the study performed by [15] Kokea (2019), the outcome shows that the integration of main performance indicators leads to effective analysis, accurate prediction and presentation.

- Applying a weighting method called W-TODIM, which is a recently developed for the cost and time estimation at completion formula. Based on the study carried out by Eshghi (2019) and his proposed model to improve the management variable aspects for a project by applying an intelligent and flexible approach to manage the uncertainty impact on project performance.

- Using weighted key project indicators (i.e. IT2F-EVM) to measure future performance which is applied in the existent case study in a Petro-refinery company which showed successful results (Amin Eshghi, 2019).

- Integrate the probabilistic character into classical EVA by improving program evaluation and review technique (PERT) to manage and control the project (Anastasiia Mishakova, 2016). 
- Adding new performance factor $\beta$ for the classical EVM approach to adjust project progress dynamically based on past performance (Batselier, 2017).

- Further control points were added to critical chain/buffer management which provides tolerance limits to generate warning signals if the project is aligned with the project baseline or not (Jeroen Colina, 2015).

- Adding a new metric for quality check system to be reported by quality discipline.

To attain project success and to improve decision-making, EVM should be applied in the simplest way taking into consideration the mentioned factors such as the risk, the sustainability of a project which influences the progress of the project positively and negatively with its uncertainties.

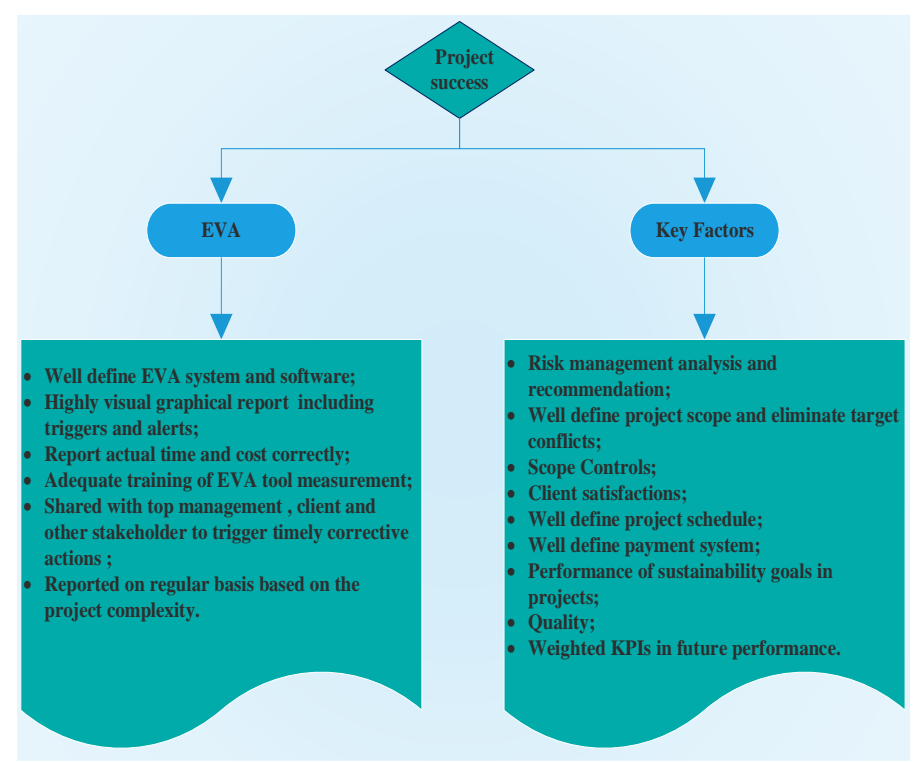

Fig. 3. Project success elements

\section{REFERENCES}

[1] Administration, N. A. (2018). Earned Value Management (EVM) Implementation Handbook. Washington, D.C. 20546: National Aeronautics and Space Administration. Humphreys \& Associates: https://ntrs.nasa.gov/adresinden alindi.

[2] De Marco, A., Briccarello, D. \& Rafele, C. (2009). Cost and schedule monitoring of industrial building projects: Case study. Journal of Construction Engineering and Management, 135(9), 853-862.

[3] Amin Eshghi, J. A. (2019). Earned Value Analysis Approach by Extending New Key Performance Indicators in a New Framework under a Grey Environment. Economic Computation And Economic Cybernetics Studies And Research, 53(3), 131-150.

[4] Eshghi, A. et al. (2019). A new interval type-2 fuzzy approach for analyzing and monitoring the performance of megaprojects based on earned value analysis (with a case study). Neural Computing and Applications, 31(9), 5109-5133.

[5] Mishakova, A. et al. (2016). Project Control Based on a Mutual Application of Pert and Earned Value Management Methods. Procedia Engineering, 165, 1812-1817.

[6] KhodaBandeh, A. (2016). Integrating Earned Value Management with Risk management To Control The Time-Cost Of The Project. Semantic Scholar: https://pdfs.semanticscholar.org/dcc8/e98602e0f968a70 0e4a5a834075636e82abb.pdf adresinden alindi.

[7] Muriana, G. et al. (2017). Project risk management: A deterministic quantitative technique for assessment and mitigation. International Journal of Project Management, 35(3), 320-340.

[8] Long Chena, H. et al. (2016). Earned value project management: Improving the predictive power of planned value. International Journal of Project Management, 34(1). https://doi.org/10.1016/j.ijproman.2015.09.008

[9] Colina, J. et al. (2015). A comparison of the performance of various project control methods using earned value management systems. Expert Systems with Applications, 42(6). https://doi.org/10.1016/j.eswa.2014.12.007

[10] Joby, D. B. (2018). Conditions of success for earned value analysis in projects. International Journal of Project Management, 36(3), 397-582.

[11] Batselier, J. et al. (2017). Improving project forecast accuracy by integrating earned value management with exponential smoothing and reference class forecasting. International Journal of Project Management, 35(1), 28-43.

[12] Chou, J.-Sh. Et al. (2010). Visualized EVM system for assessing project performance. Automation in Construction, 19(5), 596-607.

[13] Lukas, J. (2008). Earned value analysis - why it doesn't work? Ebsco-Host connection: http://icoste.org/LukasPaper.pdf adresinden alindi.

[14] McAdam, R. et al. (2014). The role of performance measurement models in multi level alignment: an exploratory case analysis in the utilities sector. Int. J. Oper. Prod. Manag. International Journal of Operations \& Production Management, 34(9), 1153-1183.

[15] Kokea, B. \& Moehler, R.C. (2019). Earned Green Value management for project management: A systematic review. Journal of Cleaner Production, 230, 180-197.

[16] Bagherpour, M., Zareei, A., Noori, S. et al. (2010). Designing a control mechanism using earned value analysis: an application to production environment. Int $J$ Adv Manuf Technol. 49, 419-429. https://doi.org/10.1007/s00170-009-2406-z

[17] PMI, (2017). A guide to the project management body of knowledge PMBOK Guide-sixth edition. Project Management Institute (PMI). 
[18] Ruskin, A. (2005). Variance analysis in earned value measurements when large uncertainties exist in underlying estimates. Aerospace Conference Aerospace 2005 IEEE, (s. 4339-4342).

[19] Mortaji, S.T.H., Noori, S., Noorossana, R. et al. (2018). An ex ante control chart for project monitoring using earned duration management observations. J Ind Eng Int., 14, 793-806. https://doi.org/10.1007/s40092-017-0251-5

[20] Souza, A. D. (2019). A Systematic Review Based on Earned Value Management and Quality. International conference on information technology, 135-141. https://www.researchgate.net/publication/333315404_A _Systematic_Review_Based_on_Earned_Value_Manag ement_and_Quality adresinden alindi.

[21] Vargas, R. (2004). Using earned value management indexes as team high tech R\&D environments. Project Management Institute. adresinden alindi. 